\title{
SYNERGY BETWEEN INDIGENOUS KNOWLEDGE SYSTEMS, MODERN HEALTH CARE SYSTEM AND SCIENTIFIC RESEARCH - A VISION FOR THE $21^{\text {ST }}$ CENTURY
}

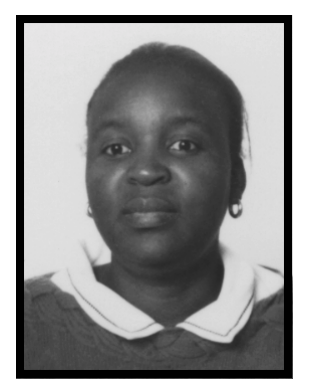

\author{
Fhumulani Mavis Mulaudzi \\ MCUR (UNISA) \\ Lecturer, Department of Nursing, University of Pretoria
}

Keywords: Synergy, modern medicine, western medicine, scientific research, traditional medicine, indigenous knowledge, traditional healers, indigenous health care.

\begin{abstract}
Research already conducted in African countries indicates that the majority of patients still seek help from the traditional indigenous health care systems. This is an indication that, to achieve the goals of Health Care for All in the $21^{\text {st }}$ century, there is a need to acknowledge the role played by indigenous health practitioners as well as those practising complementary health care methods.

The aim of the theme "African renaissance" is to focus on the renewal of African roots, which in health care is without doubt the indigenous health care methods. Although the government has already put in place mechanisms to accommodate this field of health practice, some critics still feel that the methods for diagnosis, treatment, medication as well as the training and certification are not scientific enough. It is therefore eminent that sustainable health care development that can benefit all the people of this country should harness a synergy between indigenous health care systems, scientific research and modern health care methods.

This article attempts to address the historical evolution of health care methods in South Africa, its effect on the community as well as challenges facing the health professions.
\end{abstract}

\section{OPSOMMING}

Navorsing wat reeds in Afrika-lande onderneem is, dui aan dat die meerderheid pasiënte steeds hulp soek vanaf die tradisioneel inheemse gesondheidsorgsisteme. Dit dien as aanduiding dat, ten einde die doelwitte van Gesondheidsorg vir Almal in die 21ste eeu te bereik, daar ' $n$ behoefte is om die rol wat inheemse gesondheidsorgpraktisyns speel, te erken. Dieselfde geld vir diegene wat komplimentêre gesondheidsorg metodes beoefen.

Die doelwit van die tema "Africa Rennaissance" is om te fokus op die herlewing van Afrika wortels, wat in die gesondheidsorg gewis dui op inheemse gesondheidsorgmetodes. Alhoewel die regering reeds meganismes ingestel het om hierdie veld van gesondheidsorgpraktyke te akkomodeer, is sekere kritici steeds van mening dat die metodes wat aangewend word vir diagnose, behandeling, medikasie sowel as opleiding en sertifisering, wetenskaplik nie voldoende is nie. Dit is daarom eminent dat ten einde gesondheidsorgontwikkeling vol te hou tot voordeel van al die mense in hierdie land, dit nodig is om die sinergieë wat bestaan tussen inheemse gesondheidsorgsisteme, wetenskaplike navorsing en moderne gesondheidsorgmetodes, met mekaar in te weef. Hierdie artikel poog om die historiese evolusie van gesondheidsorgmetodes in ons land, die effek 
daarvan op die gemeenskap, sowel as die uitdagings wat die gesondheidsorgprofessies in die gesig staar, aan te spreek.

\section{INTRODUCTION}

The integration of South Africa into the global community is considered as an indication that South Africa and other Third World countries have to learn and adopt the so-called global standards. However, the time has come when the world is challenged to acknowledge the significance of African medicine. This acknowledgement has greater implications in the development of a new paradigm shift in the culture of health care and nursing. Accordingly, our approach in this sphere should be guided by the perception of the clients around health issues, e.g. illnesses and health problems and the treatment thereof as well as care giving.

While not undermining the contribution of western medicine, the power of African medicine has led to the birth of new conceptualisations in medicine. As a result, one of the subjects of focus in primary health care is how to establish a synergy between indigenous knowledge systems, modern medicine and scientific research. The new paradigm questions the predominance of western medicine over the years. In agreement, Airhihenbumwa (1995:7) points out that health promotion and disease prevention practices continues to operate under the strong and direct influence of the westernised medical model. He argues that although benefits are derived from such influence, it seems unquestionable that a profession that anchors its reason in the ability to influence human behaviour has consistently undermined and in most cases ignored the centrality of culture.

The practical situation in Africa is that traditional medicine is an ever-present reality in rural, urban and peri-urban societies. Recognition of the fact that traditional healers constitute the main source of health care in the developing world has been long overdue. One reason for this has been the naive mindset of development planners that traditional healers can be wished away. Despite the introduction of modern medical care, Africans have never stopped using traditional medicine. With the advent of independence in the sixties Africans felt the need to rediscover their socio-cultural identity with traditional medicine being an integral part of their cultural heritage (Kirkland, Mathews, Sullivani \& Baldwin, 1992:12).

Abdool Karim, Ziqubu-Page and Arendse (1994:1) corroborate the above-mentioned view thus, "When an African patient consults a biomedical doctor a third figure is often present, albeit unseen". For illustration, they assert that $80 \%$ of black patients visit traditional healers before or after they have consulted a biomedical doctor. Pitje (in Blacket, 1989:26) also maintains that blacks use traditional healers because it is believed that there are certain diseases that cannot be treated by western medicine. The report of the Health Portfolio (1998) of the national assembly of the parliament of South Africa indicates that SA has approximately 350000 traditional healers who provide health services.

In the past few years, much research has been conducted on indigenous health knowledge in different health sectors such as ethno nursing, ethno botany, ethno pharmacology, ethno medicine and social sciences. This has done very little by way of increasing the recognition of the incredibly rich indigenous medicine system. Most of this research is still buried in university libraries and so far there is very little to suggest that some of it will ever see the light of day. In addition, some of the information collected has not been shared with communities and respondents themselves.

The methods used for reporting research findings and the fragmentation in our services and departments is not doing much for our cultural heritage. Furthermore, the move towards incorporating culture into nursing care and nursing education as introduced by Leininger (1994:5) in her work on 
transcultural nursing, has been much talked about without due action.

Synergy is defined as the interaction of two or more agents or forces so that their combined effect is greater than the sum of their individual effects. In this paper synergy can be defined as co-operative interaction between three different groups, namely modern medicine, scientific research and indigenous healing. The co-operation and merger between these groups may create an enhanced combined effect that will enable us to provide health care for all. For us to understand the need for synergy in research it is necessary to understand our origins and the direction we are taking into the future.

\section{HISTORICAL BACKGROUND OF TRADITIONAL HEALING}

Historically, black people depended on their natural environment for survival. Healing differed according to cultures, and in most cases it was linked to the religion of each culture. Traditional healers rendered health care in the community. They had prestige and were respected by all. They had multiple roles, which included medical specialist, religious consultant, legal and political adviser, a marriage counsellor, a police detective and a social worker. Furthermore they also acted as public health officers as they could determine were people or families may stay. Some of them were fortunetellers. Each household had their own Maine (family physician). He/she took care of the family and in cases where he/she was not sure of the diagnosis, they would refer their patients to the appropriate practitioner or specialist. Babies were born at home. Complications such as over-weight babies and CPD were not as common as the pregnant mother was encouraged or forced to follow a particular diet regime for the sake of the foetus's well-being (Mabogo, 1990:120).

Because of the prestige and status enjoyed by traditional healers in the society, it was not surprising to find that there were those who claimed to be traditional healers. To avoid such incidents, the chief and the local community acted as means of social control for the profession or apprentice. According to Mabogo (1990:120) traditional healers had a selection process, training methods, examinations as well as graduation ceremonies. In their practice traditional healers had ethics. They practiced the principle of privacy and confidentiality except in cases where witchcraft was suspected. In those cases it could be assumed that they were fulfilling a very important part of their ethics of protecting the vulnerable. They had respect for their patients and also treated clients holistically.

Colonialism and the advent of Christianity in the $17^{\text {th }}$ century and the negative propaganda against traditional healing that accompanied them did a lot of damage to this health care system. Colonialists wanted to acculturate the natives at all costs without regard for all the traditional institutions that existed, including traditional medicine. What they actually wished was complete eradication of everything traditional, which they dubbed backward, and primitive. It was thought that the then natives would become pseudo Europeans. On the other hand, missionaries regarded traditional healers as impediments to repentance. From day one both these groups went on the offensive with massive propaganda against tradition. This was ethnocentrism at its worst, which Chavunduka (1994:6) described as "a tendency to like what is familiar and devalue the strange and foreign." It is now common knowledge that all what this brouhaha achieved was to try and drive traditional medicine underground.

It should also be borne in mind that colonialism had economic implications. Western medicines have been continuously propagated and promoted thus enriching the pharmaceutical companies in those countries. As a result, any attempt towards reviewing medical approaches, such as was initi- 
ated by President Thabo Mbeki around the HIV/ aids pandemic, is generally not supported.

On the other hand, traditional medicine like modern medicine had and still has its side effects. However, wishing it away is myopic minded. On the contrary, since this phenomenon of healing has outlived some of the laws that were meant to demonise it, our present objective should be exploring the possibilities, merits and demerits of traditional and modern medicine working in tandem. In this way, traditional healers would also be protected from exploitation.

From the above discussion the following definitions are described:

Indigenous knowledge systems can be defined as "that body of accumulated wisdom that has evolved from years of experience, trial and error as well as problem solving by groups of people working to meet the challenges they face in their local environments, drawing upon the resources they have at hand" (Green, 1994:20).

Modern or scientific medicine can be defined as technology based on a knowledge system deemed superior to a pre-existing knowledge system that will hopefully be supplanted (Green, 1994:20).

\section{WHY THIS SYNERGY?}

Statistics have shown that in the South African situation, no health care system could alone be viable enough to secure health care for all (Abdool, Karim, Ziqubu-Page and Arendse (1994:1). There is therefore an imperative need for the heritage in healing to be revived and renewed. The current situation wherein the haves frown upon indigenous medicine without providing cheaper alternatives for the have-nots is by all intents and purpose not acceptable.

In her paper, Pretorius (1991:11) identifies four broad systems: The Exclusive or Monopolistic, The
Tolerant, The Inclusive or Parallel and The Integrated systems. Currently the government has been negotiating with traditional healers with the aim of exploring ways in which there could be either collaboration and/or integration.

The Health Portfolio Committee of the national assembly of South African Parliament has been looking into a possible integrative model in medical care for South Africa and the advantages and disadvantages thereof. Another recommendation was the legalisation of the profession by forming a statutory council.

All this is well, but until the need for a synergy between traditional healers, modern doctors and scientists is recognised, providing health care for all will never be fully achieved. An endeavour to collect, record, standardise and organise indigenous knowledge is important.

\section{OBJECTIVES OF FORMING A SYNERGY}

All health practitioners should recognise the importance of synergies in health care in order to:

- increase service support;

- increase business support for all the stakeholders;

- increase the stability and strength that would flow from such benefits;

- enable each group to concentrate on the training and professional advancement of its sector;

- facilitate the development of new disciplines and the harnessing of the economic benefits, for example the formation of indigenous knowledge systems departments in universities; increase economic viability in the health sector; promote interaction between members; promote scientific data gathering, correlation and dissemination of information; and revisit the curriculum to include indigenous knowledge system. 
Lastly the knowledge and expertise from different groups will be applied synergistically to the benefits of the consumers of health care systems and society at large.

The conceptual model for the envisaged synergy amongst the various health systems in South Africa can be seen below.

FACTORS THAT HAMPER SYNERGY BETWEEN MODERN MEDICINE, SCIENTIFIC RESEARCH AND INDIGENOUS HEALTH CARE METHODS

Figure 1: CONCEPTUAL FRAMEWORK

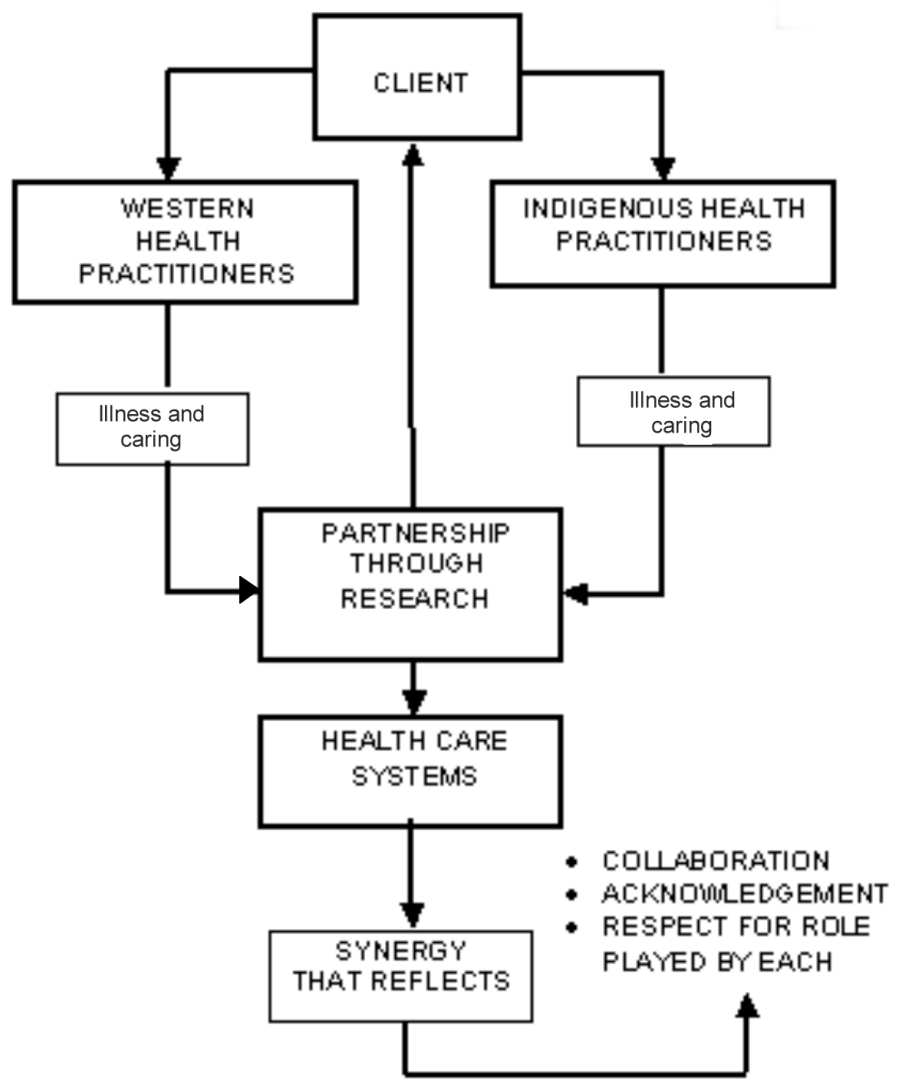

\section{Labelling}

Good (1987:xii) points out that the traditional African medical expert is prejudiced by his/her African counterparts in medical schools and hospitals. Also, their own people have dubbed traditional healers as witchdoctors. As a result, modern medical doctors would neither learn anything from traditional nor allow them to enter hospitals.

\section{Secrecy}

Knowledge of traditional medicine is not formally written down anywhere. As a result, researching and scrutinising it for efficacy is virtually impossible. Westerners in turn guard their methods through registration or induction (Good, 1987:xii).

\section{Power play}

Presently university curricula promote a distance between those who are trained in western medicine and the traditionalist thus encouraging both groups to undermine each other. Every practitioner is fighting for power and influence in society. This makes the sharing of information and methods of healing impossible (Good, 1987:xiii).

\section{RECOMMENDATIONS}

\section{The co-operation model}

Pretorius (1991:11) has described this model as a model whereby both the traditional healers and modern medicine practitioners co-exist as two independent sectors each representing the uniqueness of the other. This view was supported by the recommendations of the Portfolio Committee of the national assembly of the parliament of South Africa (1998). Furthermore the two reports agreed that the model could be achieved though:

education

\section{mutual referral}

professionalisation of traditional medicine, protection of natural resources, and scientific research.

\section{Education}

There is a need to include traditional healing as a field of medicine taught in nursing schools, technikons and universities. This is a very important challenge for all health professionals, particularly within the context of African renaissance. While in the past curricula were based on western 
paradigms, the student of the $21^{\text {st }}$ century has a right to know his/her roots. Underlying this need is a challenge for curricula to be revamped to make provision for a choice between indigenous knowledge, modern medicine or both.

In the $21^{\text {st }}$ century, those who were previously disadvantaged should play an important role in designing new curricula that seek to fill out the knowledge gap of the past. The major challenge is how to harmoniously integrate western health care methods and traditional medicine in both theory and practice. While not undermining the possible challenges inherent in the task, considering the current training, with dedication, enthusiasm and change of behaviours and attitudes this task can be accomplished.

\section{Mutual referral}

Mutual referral is only achievable in a climate whereby people respect each other's uniqueness and competency. Such a climate requires a commitment from health care facilities in tertiary level institutions to facilitate proper training programmes. There is a fundamental need for healers from the respective backgrounds to have basic training pertaining to each other's medical expertise. Both patients and practitioners stand to benefit from such a mutual interchange. Patients would be assured of a more improved quality care while practitioners on the other hand would be more knowledgeable and thus more efficient in their service.

There is a need to conduct in-service training for those that are already in practice. The focal point of the in-service training programmes should be on the rebirth of attitudes. Our education has so distanced us from the community that we serve that we have even branded them with words such as laypersons and heathens. We feel they are now inferior as their beliefs are no longer the same as ours. The understanding and respect of our roots will enable us to understand our clients more.
Furthermore, it will also enable consumers of health care to have a wide choice in terms of the appropriate therapy they require.

\section{Professionalisation of traditional medicine}

The possibility of forming a statutory council to govern the practice of traditional healers has been explored and it is now in process. This will help to protect the public from exploitation. The statutory body will also try to regulate the standards of training, scientific research in pharmacoepia as well as foster co-operation and collaboration amongst the different health care systems.

\section{Protection of natural resources}

There is a need for mechanisms to be put in place to protect natural resources and oversee the cultivation and harvesting thereof. In addition, procedures need to be formulated to protect the rights of traditional healers by binding researchers to acknowledge the origins of their findings and communicate them to traditional healers.

\section{Scientific research methodology}

The kinds of scientific research methodology currently in use tend to alienate other groups. For example, Africans believe in oral evidence. Story telling is one of their strengths. This mode is partially used in qualitative methodology and narrative methods. However, problems arise with the need to establish the validity and reliability of the information gathered in that way.

\section{CONCLUSION}

There is no doubt about the significant contribution of African traditional medicine in the envisaged new health care system. However, it will appear as if the challenge facing the government as a facilitator is how to ensure the commitment of various stakeholders towards carrying the implementation process forward.

The first challenge facing South Africa is to de- 
sign an implementable model that is specifically centred around the needs of the people of this country. Secondly, we must find out what institutional framework should be put in place to drive this process. Finally, we must clarify which mechanisms and processes should be put in place to ensure successful implementation.

My observation is, without the necessary resources for implementation, the health models that we envisage may not be a reality.

\section{REFERENCES}

Abdool Karim, SS; Ziqubu-Page, TT \& Arendse, R 1994: Bridging the gap: Potential for health care partnership between African healers and biomedical personnel in South Africa. South African Medical Journal, December 1994, 84(2), pp. $2-16$.

Airhihenbumwa, C 1995: Health and Culture Beyond the Western Paradigm. California:Sage Publishers.

Blacket, Y 1989: Traditional healers and mental health in SA. Johannesburg: RAU.

Bodibe, WJM 1988: Inclusion of traditional healers in mental health team. Social Work perspective. Pretoria: Unisa.

Chavunduka, GL 1994: Traditional medicine in modern Zimbabwe. Harare: University of Zimbabwe.

Good, CM 1987: Ethomedical systems in Africa. New York: Guilford

Green, E 1994: AIDS and STDs in South Africa: Bridging the gap between traditional healing and modern medicine. Pietermaritzburg: University of Natal press.

Kirkland, J; Mathews, H; Sullivani CW \& Baldwin, K 1992: Herbal and magical medicine: Traditional healing today. United States of America: Duke University Press.

Leininger, M 1994: Transcultural nursing concepts, theories and practices. New York: John Wiley \& Sons.

Mabogo, DEN 1990: Ethnobotany of the Vhavenda. Pretoria: University of Pretoria.

Pretorius, E 1991: Traditional healing and modern medicine working in tandem. Curationis, December 1991, 14(4), pp. 10-12.

Traditional healers: A report by the national assembly portfolio committee on health and the NCOP select committee on social service.1998. Cape Town: Government Printers. 